\title{
Glaciological measurements and mass balances from Sperry Glacier, Montana, USA, years 2005-2015
}

\author{
Adam M. Clark ${ }^{1}$, Daniel B. Fagre ${ }^{1}$, Erich H. Peitzsch ${ }^{1}$, Blase A. Reardon ${ }^{2}$, and Joel T. Harper ${ }^{3}$ \\ ${ }^{1}$ US Geological Survey, Northern Rocky Mountain Science Center, 215 Mather Drive, \\ Glacier National Park, West Glacier, MT 59936, USA \\ ${ }^{2}$ Colorado Avalanche Information Center, 1611 Defiance Dr, Carbondale, CO 81623, USA \\ ${ }^{3}$ Department of Geosciences, The University of Montana, 32 Campus Drive \#1296, \\ Missoula, MT 59812-1296, USA \\ Correspondence to: Adam M. Clark (amclark@usgs.gov)
}

Received: 11 August 2016 - Published in Earth Syst. Sci. Data Discuss.: 13 September 2016

Revised: 10 December 2016 - Accepted: 15 December 2016 - Published: 23 January 2017

\begin{abstract}
Glacier mass balance measurements help to provide an understanding of the behavior of glaciers and their response to local and regional climate. In 2005 the United States Geological Survey established a surface mass balance monitoring program on Sperry Glacier, Montana, USA. This project is the first quantitative study of mass changes of a glacier in the US northern Rocky Mountains and continues to the present. The following paper describes the methods used during the first 11 years of measurements and reports the associated results. From 2005 to 2015, Sperry Glacier had a cumulative mean mass balance loss of $4.37 \mathrm{~m}$ w.e. (water equivalent). The mean winter, summer, and annual glacier-wide mass balances were $2.92,-3.41$, and $-0.40 \mathrm{~m}$ w.e. $\mathrm{yr}^{-1}$ respectively. We derive these cumulative and mean results from an expansive data set of snow depth, snow density, and ablation measurements taken at selected points on the glacier. These data allow for the determination of mass balance point values and a time series of seasonal and annual glacier-wide mass balances for all 11 measurement years. We also provide measurements of glacier extent and accumulation areas for select years. All data have been submitted to the World Glacier Monitoring Service and are available at doi:10.5904/wgmsfog-2016-08. This foundational work provides valuable insight about Sperry Glacier and supplies additional data to the worldwide record of glaciers measured using the glaciological method. Future research will focus on the processes that control accumulation and ablation patterns across the glacier. Also we plan to examine the uncertainties related to our methods and eventually quantify a more robust estimate of error associated with our results.
\end{abstract}

\section{Introduction}

The worldwide retreat of glaciers in the past century is seen as both an effect of and evidence for global climate change (Roe et al., 2016). In the United States, one example of this global trend is the retreat of glaciers in Glacier National Park (GNP), which is located in the Rocky Mountains of northwest Montana (Fig. 1). In 1850, during a period known as the Little Ice Age, approximately 150 glaciers existed in the area now encompassed by GNP, making it one of the largest concentrations of glaciers in the US Rocky Mountains (Key et al., 2002; Pedersen et al., 2004). The amount of glacier- covered area has receded dramatically since that time, a trend documented by decades of photographs and measurements of glacier area (Alden, 1914, 1923; Dyson, 1948; Johnson, 1980; Carrara and McGimsey, 1981, 1988; Carrara, 1989; Key et al., 2002). By 1998, 37 named glaciers remained; 11 of these had a total surface area of $8.25 \mathrm{~km}^{2}$, a $67 \%$ loss compared with $25.5 \mathrm{~km}^{2}$ for the same 11 glaciers in 1850 (Key et al., 2002). The fraction of glacier area lost since 1900 is markedly higher in GNP than in the other mountain regions of the contiguous United States (Fountain, 2007).

This trend and its effects are expected to continue. One geospatial model scenario predicts a complete disappearance 


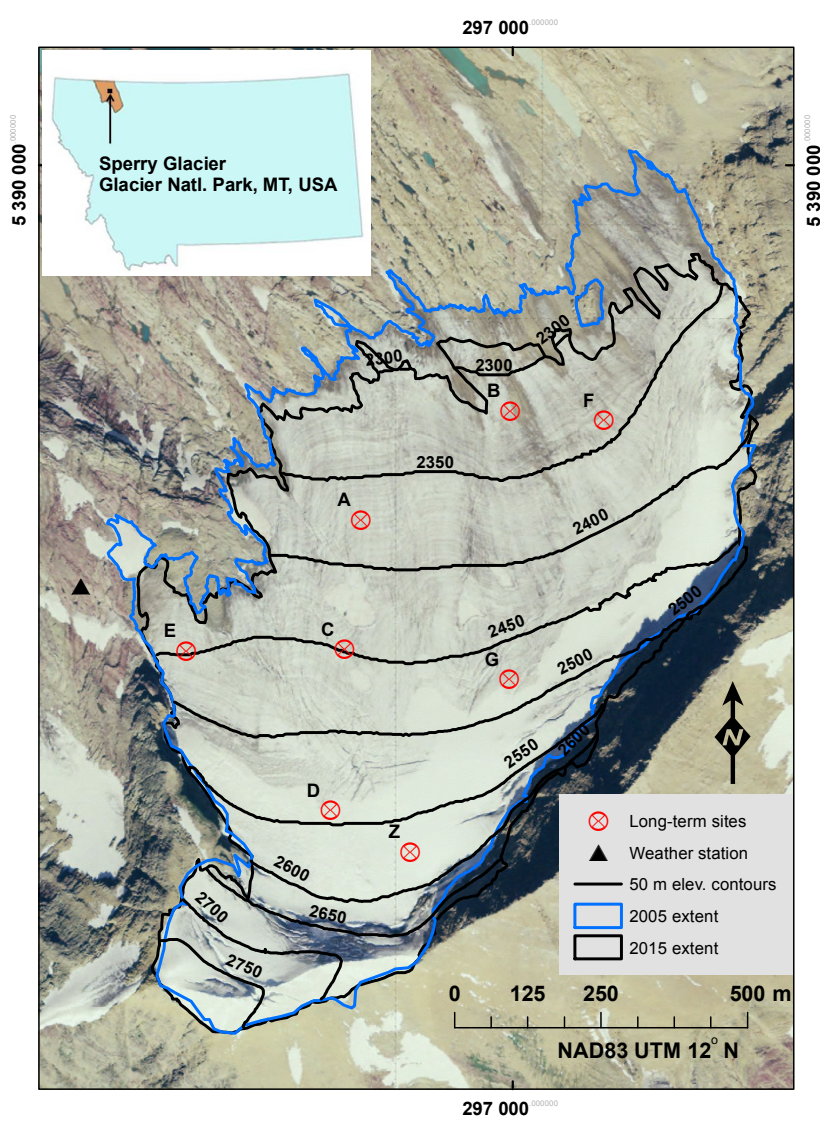

Figure 1. An overview map of Sperry Glacier which displays the locations of the long-term measurement sites and the weather station, plus changes in glacier extent between 2005 and 2015. Glacier surface elevations are contoured from a DEM derived from imagery pairs taken on 2 September 2005. The aerial photo in this figure was taken on 26 August 2005 by the US National Agricultural Imagery Program.

of five glaciers in GNP by 2030 with continued warming (Hall and Fagre, 2003). Another process-based model that specifically examines Sperry Glacier suggests the glacier may last until about 2080 given the current climate and glaciological conditions (Brown et al., 2010). The retreat of glaciers in GNP has had and will continue to have hydrologic and ecological effects in the region's mountain ecosystems and some degree of economic effect for its human communities (Clark et al., 2015).

It is widely accepted that the regional retreat of glaciers has been driven by climate change (Roe et al., 2016), at least some of which is anthropogenic (IPCC, 2013). However, no quantitative measurements of mass changes have ever been conducted for any glacier in GNP. Without such studies, it is difficult to determine whether or how the retreat of GNP's glaciers directly reflects regional climate trends. To address this gap, the US Geological Survey (USGS, 2016) established a long-term mass balance monitoring program in which glaciological, surface area, and hypsometric mea- surements provide a quantitative estimate of mass changes for one glacier in the park, Sperry Glacier. The changes and trends measured on this glacier are meant to serve as a reference for others in the region, an approach outlined by Fountain et al. (1997) and since adopted widely (Kaser et al., 2003). Sperry Glacier is now one of four benchmark glaciers studied by the USGS Glaciers and Climate Program, with two benchmark glaciers located in Alaska and one in Washington (USGS Glacier Studies).

This paper presents the data collection methods and results from the first 11 years of measurements, from 2005 to 2015. Results include measurements of glacier area, snow depth, snow density, and ablation of snow, firn, and ice. We calculate the associated point balance values (Cogley et al., 2011) for the snow depth and ablation measurement sites. We also compute and report conventional glacier-wide seasonal and annual mass balances (Cogley et al., 2011) for the same period. Results from this work will improve our understanding of glacier responses to climate in GNP as well as the role of glaciers as a water resource. The data sets included in this paper and the associated Supplement may also be used for general analysis of regional and global glacier mass balance trends.

\subsection{Sperry Glacier site description}

Sperry Glacier $\left(48.623^{\circ} \mathrm{N}, 113.758^{\circ} \mathrm{W}\right)$ is a small cirque glacier located immediately west of the Continental Divide and roughly in the geographic center of GNP (Fig. 1). The remote location limits the type and manner of research that can be undertaken at the site. Sperry Glacier is located in a backcountry zone managed as de facto wilderness by the US National Park Service. Helicopter access to the glacier is very limited due to environmental and cultural concerns as well as management policies. Therefore, with very few exceptions, all equipment and instruments must be backpacked to the glacier, which requires a $15 \mathrm{~km}$ hike or ski with over $1500 \mathrm{~m}$ of elevation gain.

Sperry was chosen as a site for surface mass balance measurements because of two factors that are rare in the region. First, it has a history of previous scientific studies that documents its progressive retreat over the past century (Johnson, 1980). Second, its physical characteristics best meet those recommended for detailed mass balance studies and regional benchmark glacier status (Fountain et al., 1997; Kaser et al., 2003). These characteristics include a well-defined drainage basin and topographic features that are representative of many of GNP's glaciers.

Sperry is a winter-accumulation type glacier composed of temperate ice. In 2015 the total surface area measured $0.78 \mathrm{~km}^{2}$. It is located within the Flathead River watershed, in the headwaters of the Columbia River basin. It lies in a north-facing cirque and is roughly fan-shaped and wider than it is long relative to the flow direction, which is predominantly north-northeast (Fig. 2). The irregular terminus mea- 


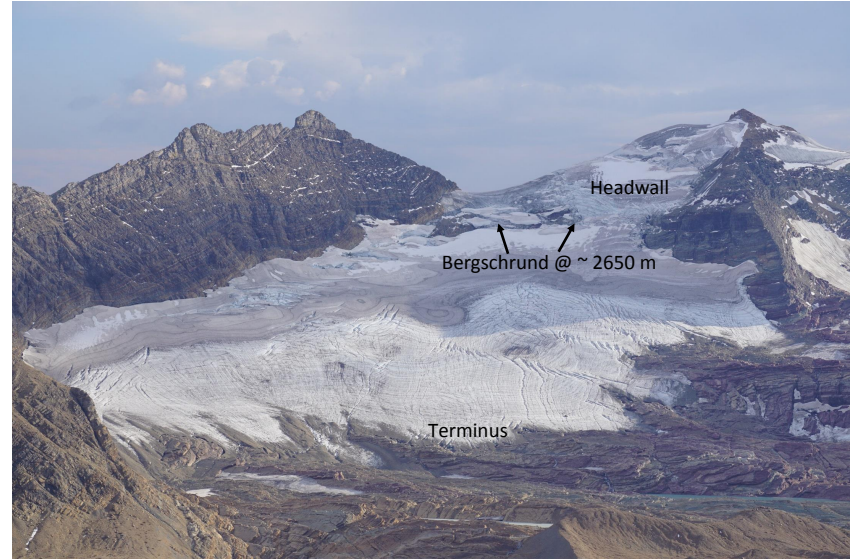

Figure 2. Oblique photo showing overview of the glacier, the bergschrund, and headwall. Photo taken by Adam Clark (USGS) on 25 September 2015.
Table 1. List of acquisition dates for aerial photographs and measured terminus positions used to derive each DEM and AAD.

\begin{tabular}{lrr}
\hline AAD year & DEM date & $\begin{array}{r}\text { Glacier margin } \\
\text { measurement date }\end{array}$ \\
\hline 2005 & $9 / 2 / 2005$ & $9 / 9 / 2005$ \\
2006 & $9 / 2 / 2005$ & $9 / 9 / 2005$ \\
2007 & $8 / 25 / 2007$ & $9 / 8 / 2007$ \\
2008 & $9 / 11 / 2008$ & $9 / 8 / 2007$ \\
2009 & $8 / 28 / 2009$ & $8 / 26 / 2009$ \\
2010 & $8 / 28 / 2009$ & $8 / 26 / 2009$ \\
2011 & $8 / 10 / 2011$ & $8 / 26 / 2009$ \\
2012 & $8 / 10 / 2011$ & $8 / 26 / 2009$ \\
2013 & $8 / 21 / 2013$ & $9 / 4 / 2013$ \\
2014 & $9 / 7 / 2014$ & $9 / 4 / 2013$ \\
2015 & $9 / 7 / 2014$ & $9 / 25 / 2015$ \\
\hline
\end{tabular}

about 1 May each year but can vary by up to four weeks earlier or later (US Natural Resources Conservation Service).

\section{Methods}

\subsection{Glacier geometry and accumulation area mapping}

Initially, the surface area of Sperry was mapped using aerial photographs taken in September 1998. To ensure that mass balance calculations included the most current estimates of the glacier surface, we mapped the terminus using multichannel GPS receivers at the end of the 2003, 2005, 2007, 2009, and 2013 ablation seasons. We conducted the mapping by walking the terminus (Fig. 2) of the glacier, with the terminus defined as any ice contiguous with the main body even if debris-covered. We did not map the glacier margin below the near-vertical cirque walls that rise above the upper elevation margins of the glacier for safety reasons.

We differentially corrected the GPS data collected during the mapping, then smoothed the track by removing obvious errors such as loops caused by the mapper's movement. We overlaid each mapped terminus with a polygon of the 1998 glacier outline and calculated the area of each resulting polygon for each year. For these years, the resulting values should be considered the maximum possible glacier extent for a given year because they do not include any small changes at the glacier margins below the steep cirque walls or on the ridge above the headwall. In 2015 the complete glacier margin was mapped again from $0.5 \mathrm{~m}$ resolution aerial imagery and included area changes across the entire glacier including the margins along the flanks and head of the glacier.

During years 2005, 2009, 2010, and 2013 we walked the seasonal snow line with a GPS unit at the end of the ablation season. This end-of-summer snow line separates the ablation and accumulation areas on the glacier since the area at elevations above this line were still covered with snow that accumulated the previous winter. We divided these mapped 
accumulation areas by the total area of the glacier to obtain the accumulation area ratio (AAR).

Area altitude distributions (AADs) were calculated for 8 years of the 11-year study period (Table 1) from a time series of digital elevation models (DEMs). These DEMs were derived from aerial photographs taken of the glacier in August or September so as to capture the glacier near its mass minimum (Fahey, 2014). Fahey used Next-Generation Automatic Terrain Extraction (NGATE; Zhang et al., 2006a, b) and SOCET SET ${ }^{\circledR}$ software to derive DEMs from the aerial imagery. Horizontal grid cell size was $5 \mathrm{~m}$ and the relative horizontal and vertical errors were less than $1 \mathrm{~m}$. Since we used each DEM in isolation to generate Sperry Glacier altitude distributions for selected years, the DEMs were not co-registered to each other and we consider the relative error more pertinent to our analysis. The raw DEM coverage reached beyond the glacier's margin so each DEM was clipped by the most recently measured glacier margin so that all cells in the DEM represent snow-, firn-, and ice-covered area. Each cell from these glacier DEMs was then binned into $50 \mathrm{~m}$ bands and then summed to derive the total area for each elevation band.

\subsection{Study assumptions and conventions}

For this study, we determined conventional (Cogley et al., 2011) seasonal and annual surface mass balances for Sperry Glacier using the glaciological method combined with the most recently mapped glacier margin and AAD. We followed established protocols for measuring snow depth, sampling snow density, and installing and reading ablation stakes (Ostrem and Brugman, 1991; Kaser et al., 2003). The snow depth measurements included all snow deposited on the glacier surface during the winter season, including seasonal snowfall, avalanche debris, and wind-transported snow. Because we were not able to directly measure melt that occurred during the winter season, we did not specifically account for it in the winter balance terms of mass balance calculations. Similarly, we did not include summer-season precipitation in our summer balance terms because it fell primarily as rain and was assumed to run off and not measurably contribute to the glacier's mass change. In addition, local climate data (Finklin, 1986) show that both winter-season melt and summerseason precipitation likely have minimal contributions to the net balances of each period. Because Sperry Glacier is a small, temperate glacier, we assumed that runoff transported nearly all melt off the glacier with negligible mass retained by refreezing and/or the formation of superimposed ice. This is a common assumption (Kaser et al., 2003) and is supported by our field observations and observations in the North Cascade Mountains, USA (Pelto, 1996).

We determined the mass balance year for field measurements and balance calculations using a time system that combines the stratigraphic and floating-date systems (Cogley et al., 2011). Ideally, measurements of accumulation are con- ducted when the glacier's mass is at its maximum for the year and ablation measurements during its minimum, with the balance year the period between two consecutive minima. For Sperry, such timing is impractical because difficulties with access preclude continuous monitoring. Also the time of the maxima and minima can vary by several weeks between years.

We therefore defined each mass balance year as the period between the latest ablation stake readings in successive summer seasons (Table 2). These readings were timed to occur as late as possible in September or early October of each calendar year, so as to coincide as closely as possible with the formation of that year's end of summer surface, which represents the minimum annual mass for that year. We used the previous summer's surface as the reference surface for snow depth probing at the end of the subsequent accumulation season and defined winter balances $b_{\mathrm{w}}$ (winter point balances) and $B_{\mathrm{w}}$ (winter glacier-wide balances) as the net mass gain between formation of the previous year's summer surface and the subsequent year's peak accumulation. We defined summer balances $b_{\mathrm{s}}$ (summer point balances) and $B_{\mathrm{s}}$ (summer glacier-wide balances) as the net mass loss between the peak accumulation, approximated by the earliest date in the spring when depth measurements and ablation stake installations occurred, and the formation of that year's end of summer surface. Under these definitions, the winter season at Sperry Glacier typically runs from mid-September/early October to late May/late June, with the summer season comprising the remaining part of the year (Table 2). The balance year is thus roughly equivalent to the 1 October-30 September hydrologic year.

We adhered to the notation and signing conventions delineated in Cogley et al. (2011) and used terms as defined in that glossary. The dimensions of the depth and surface altitude measurements are length $(\mathrm{m})$. Multiplying these by the sampled snow density or, for firn and ice, an assumed density of 720 and $874 \mathrm{~kg} \mathrm{~m}^{-3}$ respectively yields a mass per unit area whose units are $\mathrm{kg} \mathrm{m}^{-2}$ of water equivalent. Because mass balance is a rate of mass change, its dimensions are mass per unit time $\left(\mathrm{M} \mathrm{T}^{-1}\right)$, though as is common in mass balance studies, we report mass primarily in length $(\mathrm{m})$ of water equivalent (w.e.) because it allows for ease of visualization and we omit the time dimension as our measurements span roughly one year (Cogley et al., 2011). Thus all balances are reported in meters of water equivalent ( $m$ w.e.) for each year in the 11-year study period.

\subsection{Mass balance point measurements $\left(b_{\mathrm{w}}, b_{\mathrm{s}}, b_{\mathrm{a}}\right)$}

A winter mass balance point measurement $\left(b_{\mathrm{w}}\right)$ is the sum of accumulation and, to a much lesser extent, ablation over the winter season. It represents nearly all the annual mass input at any point that accumulates continuously as precipitation and as wind and avalanche deposited snow. To obtain $b_{\mathrm{w}}$ we 
Table 2. Dates for mass balance years and winter and summer seasons for the study years, 2005 through 2015.

\begin{tabular}{llllrrr}
\hline $\begin{array}{l}\text { Mass } \\
\text { balance } \\
\text { (MB) year }\end{array}$ & $\begin{array}{l}\text { Start MB } \\
\text { year \& } \\
\text { winter season }\end{array}$ & $\begin{array}{l}\text { End winter } \\
\text { season \& } \\
\text { start summer season }\end{array}$ & $\begin{array}{l}\text { End summer } \\
\text { season \& } \\
\text { end MB Year }\end{array}$ & $\begin{array}{r}\text { No. days } \\
\text { winter } \\
\text { season }\end{array}$ & $\begin{array}{r}\text { No. days } \\
\text { summer } \\
\text { season }\end{array}$ & $\begin{array}{r}\text { No. days } \\
\text { MB Year }\end{array}$ \\
\hline 2005 & Unknown & 23-Jun-05 & 9-Sep-05 & Unknown & 78 & Unknown \\
2006 & 9-Sep-05 & 8-Jun-06 & 28-Sep-06 & 272 & 112 & 384 \\
2007 & 28-Sep-06 & 26-May-07 & 9-Sep-07 & 240 & 106 & 346 \\
2008 & 9-Sep-07 & 16-Jun-08 & 12-Sep-08 & 281 & 88 & 369 \\
2009 & 12-Sep-08 & 16-Jun-09 & 18-Sep-09 & 277 & 94 & 371 \\
2010 & 18-Sep-09 & 23-Jun-10 & 2-Oct-10 & 278 & 101 & 379 \\
2011 & 2-Oct-10 & 24-Jun-11 & 3-Oct-11 & 265 & 101 & 366 \\
2012 & 3-Oct-11 & 28-Jun-12 & 1-Oct-12 & 269 & 95 & 364 \\
2013 & 1-Oct-12 & 11-Jun-13 & 27-Sep-13 & 253 & 108 & 361 \\
2014 & 27-Sep-13 & 11-Jun-14 & 18-Sep-14 & 257 & 99 & 356 \\
2015 & 18-Sep-14 & 25-May-15 & 22-Sep-15 & 249 & 120 & 369 \\
Mean & 21-Sep & 13-Jun & 21-Sep & 264 & 100 & 367 \\
Min & 9-Sep & 25-May & 9-Sep & 240 & 78 & 346 \\
Max & 3-Oct & 28-Jun & 3-Oct & 281 & 120 & 384 \\
\hline
\end{tabular}

combined snow depth measurements taken at locations on the glacier with a snow density value (Supplement).

A summer mass balance point measurement $\left(b_{\mathrm{s}}\right)$ represents the sum of ablation and, to a much lesser extent, any accumulation over the summer season. To obtain $b_{\text {s }}$ we measured the height loss on ablation stakes that were drilled into the glacier's surface (Supplement) at the start of the ablation season.

An annual mass balance point measurement $\left(b_{\mathrm{a}}\right)$ represents the sum of accumulation and ablation over the mass balance year. These were calculated by summing the winter balance $\left(b_{\mathrm{w}}\right)$ and summer balance $\left(b_{\mathrm{s}}\right)$ values measured at each ablation stake site (Supplement) for each respective year.

\subsubsection{Snow depth and density measurements}

The primary method for taking snow depth measurements was to probe vertically through the seasonal snowpack to the previous summer surface. A sectional solid aluminum probe was used, and depths were measured to the nearest 0.01 or $0.05 \mathrm{~m}$ depending on the year. Measurement locations were recorded using handheld GPS receivers. Depending on the GPS equipment available, some locations were differentially corrected. For safety reasons, we made no measurements on the steep headwall above the bergschrund (Fig. 2).

All measurements of snow density were taken in the spring. In 2005, density measurements were made in two snow pits (Supplement). The first pit was located roughly $275 \mathrm{~m}$ above the terminus; the second pit was $500 \mathrm{~m}$ farther up the glacier, roughly $125 \mathrm{~m}$ below the bergschrund. During 2006, 2007, and 2008 measurements were made at one pit dug at the lower location. From 2009 to 2013 no density measurements were made on the glacier and a bulk density

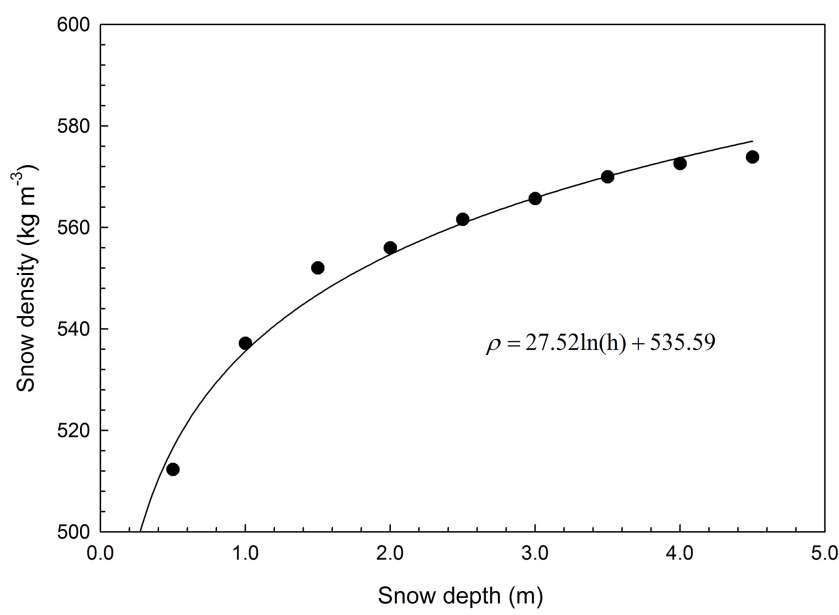

Figure 3. Logarithmic curve fit to the three-pit mean data from June 2005 and 2006. Here $h$ is snow depth in meters and $\rho$ is a density value $\left(\mathrm{kg} \mathrm{m}^{-3}\right)$

value derived from the relationship between snow depth and density using the 2005-2006 data was employed to calculate balances. Density measurements resumed in 2014 and were taken at ablation stake sites A, C, and D that year, and at sites $\mathrm{A}$ and $\mathrm{D}$ in 2015.

For the years 2005-2008, direct density measurements were made by weighing samples of snow from the shaded face of a snow pit. The samples were collected in $10 \mathrm{~cm}$ increments with a $1000 \mathrm{~cm}^{3}$ cutter and weighed on a digital scale. Snow pits were dug to the previous summer's surface in 2005 and 2006 when the snow depth was less than $4.75 \mathrm{~m}$. During 2007 and 2008 when the height of snow was greater than $5 \mathrm{~m}$, the snow was sampled only in the upper $2.0-3.5 \mathrm{~m}$ portion of the column. 
In 2014 and 2015 density was measured by weighing snow samples collected at three or four specific depths in a $1.5 \mathrm{~m}$ deep snow pit. One sample was taken within $0.10 \mathrm{~m}$ of the snow surface, the second at about $1.0 \mathrm{~m}$, and the third at about $1.5 \mathrm{~m}$. At depths greater than $1.5 \mathrm{~m}$ from the snow surface, snow samples were obtained using a coring cylinder at 0.10 to $0.30 \mathrm{~m}$ intervals until the previous summer's surface was reached. Densities were then derived by weighing these samples.

During years 2005 and 2006 we adopted the methods of Jansson (1999) and calculated the mean of the density measurements at $0.5 \mathrm{~m}$ intervals, providing a bulk density for the first $0.5 \mathrm{~m}$ below the snow surface, then 1.0 , and $1.5 \mathrm{~m}$, continuing down to the deepest measurements for each snow pit. A logarithmic curve was then fit to these values, resulting in a function, $\rho=27.52 \ln (h)+535.59$ (Fig. 3). Here $h$ is snow depth in meters and $\rho$ is a single density value $\left(\mathrm{kg} \mathrm{m}^{-3}\right)$ used to estimate the bulk density for any snow depth measured on the glacier. Employing this modeled depth-density relationship reduces the influence of high-frequency variability that may result from measurement error. We also employed this function to acquire bulk densities for balance years 20092013 for which there are no density measurements (Supplement).

In 2007 and 2008 the data did not trend like the measurements from 2005 and 2006 and no model could adequately explain the relationship between depth and density. To calculate winter balances we instead used the bulk mean density derived from all values measured in the snow pit.

For balance years 2014 and 2015, we applied the measured densities taken from their respective depths in the column to calculate water equivalents layer by layer and then summed these values to get $b_{\mathrm{w}}$. At stake sites with no density measurements, we calculated a mean density by dividing the $b_{\mathrm{w}}$ values at the three measured sites by the depths at these same sites. This single average density value was then used to calculate $b_{\mathrm{w}}$ at the remaining sites.

\subsubsection{Ablation measurements}

We measured the surface change at the ablation stake locations and obtained a water-equivalent length value for the total ablation by multiplying the height loss of snow, firn, and ice by their respective densities. We used the same density value for the snow component of $b_{\mathrm{s}}$ as used to calculate $b_{\mathrm{w}}$ at that point. We used previously published estimates of the densities of firn and ice to account for mass loss of those components (Cuffey and Paterson, 2010). We used a value of $720 \mathrm{~kg} \mathrm{~m}^{-3}$ for firn, which equals the mean between the approximate maximum densities of snow $\left(600 \mathrm{~kg} \mathrm{~m}^{-3}\right)$ and firn $\left(840 \mathrm{~kg} \mathrm{~m}^{-3}\right)$. For ice melt on the glacier's surface we used a density of $874 \mathrm{~kg} \mathrm{~m}^{-3}$, the mean value for glacier ice as described by Cuffey and Paterson (2010).

\subsection{Glacier-wide mass balances $\left(B_{\mathrm{w}}, B_{\mathrm{s}}, B_{\mathrm{a}}\right)$}

Glacier-wide mass balances represent the mean balance for the infinite number of possible points across the glacier's surface. These values cannot be directly measured and are typically estimated from point measurements or interpolations of point measurements. We estimate glacier-wide mass balances for the winter $\left(B_{\mathrm{w}}\right)$ and summer $\left(B_{\mathrm{S}}\right)$ seasons as well as an annual balance representing the entire mass balance year $\left(B_{\mathrm{a}}\right)$. We used the site-index method where one or more point balances in a specific elevation band represent the average balance across the entire surface area for that elevation band. Balances in each respective band were multiplied by the band's area yielding a volume. Volumes from each band were summed, and then this quantity was divided by the glacier's total surface area to provide the specific glacierwide mass balance value. The number and size of the elevation bands varied slightly between years depending on the point balances available and the changing geometry of the glacier. In the case where more than one point balance was located within a band, we use the mean value.

Differences between winter point balances within bands varied between 0 and $5.05 \mathrm{~m}$ w.e. In most cases winter point balances in the same band differed by less than $1.5 \mathrm{~m}$ w.e. There were two instances in the 11-year record when there was bare ice and a high amount of accumulation in the same elevation band, resulting in differences greater than $4 \mathrm{~m}$ w.e. Summer point balances within bands varied much less, ranging between 0.01 to $0.82 \mathrm{~m}$ w.e. In $68 \%$ of cases the difference was less than $0.5 \mathrm{~m}$ w.e. Annual point balances located in the same elevation band were slightly more variable than the summer balances but still less variable than winter balances. Differences ranged from 0.01 to $1.98 \mathrm{mw}$.e. and in $71 \%$ of cases the difference was less than $1 \mathrm{~m}$ w.e.

During some years no measurement points were located at the very lowest elevations of the glacier below $2300 \mathrm{~m}$. In these cases, measurement points within $10 \mathrm{~m}$ of $2300 \mathrm{~m}$ were used to assign balances to this elevation band. In situations where this was not possible, then a single point balance, taken from the lowest elevation measurement point, was used instead (Supplement). For some balance years there were no measurements taken at the higher elevations of the glacier between 2550 and $2650 \mathrm{~m}$ (Supplement). The winter and summer balances for these bands were derived using a gradient found between two point balances and their respective elevations at two different measurement sites. The stakes used to calculate these gradients are presented in the data tables included in our Supplement. Furthermore, no measurements of any kind have been collected at the uppermost elevations of the glacier on the steep southern headwall above $2650 \mathrm{~m}$. With respect to the winter balance, observations show that frequent avalanches prevent large amounts of snow from accumulating on this steep slope. Thus it is likely winter balances will be lower on areas above the bergschrund than those immediately below it. For the area located on this head- 
Table 3. Sperry Glacier areal extent, 2005-2015.

\begin{tabular}{llrrrrr}
\hline Year & $\begin{array}{l}\text { Measurement } \\
\text { date }\end{array}$ & $\begin{array}{r}\text { Measured } \\
\text { area } \\
\left(\mathrm{km}^{2}\right)\end{array}$ & $\begin{array}{r}\Delta \\
\text { area } \\
\left(\mathrm{km}^{2}\right)\end{array}$ & $\begin{array}{r}\% \\
\text { change } \\
\text { in area }\end{array}$ & $\begin{array}{r}\text { Rate }- \\
\text { area/ } \Delta \\
\text { years }\left(\mathrm{km}^{2}\right)\end{array}$ & $\begin{array}{r}\text { Rate }- \\
\text { change area/ } \Delta \\
\text { years }\end{array}$ \\
\hline 2005 & 9-Sep & 0.86 & 0.00 & 0.0 & 0.000 & 0.0 \\
2007 & 8-Sep & 0.84 & -0.02 & -2.3 & -0.010 & -1.2 \\
2009 & 26-Aug & 0.83 & -0.01 & -1.0 & -0.004 & -0.5 \\
2013 & 4-Sep & 0.82 & -0.01 & -1.2 & -0.002 & -0.3 \\
2015 & 25-Sep & 0.78 & -0.04 & -5.5 & -0.022 & -2.8 \\
\hline
\end{tabular}

wall, we used the mean winter point balance taken from all measurement points on the glacier to represent winter balances. Ultimately the snow depths on the headwall are unknown, yet it is necessary to assign balances to this region. Using the mean $b_{\mathrm{w}}$ is a method to accomplish this while minimizing the influence of these uncertain balances on $B_{\mathrm{w}}$. For the summer balances on the headwall we again used a gradient value derived from an ablation versus elevation relationship observed at two different stake sites (Supplement).

Annual balances for elevation bands with no point balances were derived by summing the winter and summer values assigned to them via the extrapolation methods discussed above. This sometimes resulted in negative balances on the steep southern headwall. This is consistent with observations showing much of this headwall will melt down to firn and ice during years with a strongly negative $B_{\text {a }}$ despite the fact this is the highest elevation region of the glacier (Fig. 2).

\subsection{Cumulative mass balance}

The cumulative mass balance is the total mass gained or lost over multiple balance years. For this study, we calculated cumulative mass balances for the 11 study years by summing the glacier-wide annual $\left(B_{\mathrm{a}}\right)$ balances.

\section{Results and discussion}

\subsection{Glacier mapping - terminus position and glacier area}

Sperry Glacier has decreased by $0.08 \mathrm{~km}^{2}$ in total area since 2005 at an average rate of $0.007 \mathrm{~km}^{2} \mathrm{a}^{-1}$ (Table 3). Overall the terminus continually retreated with each measurement interval. However there are selected small areas where the terminus has slightly advanced. The largest changes occurred around the glacier's northernmost edges, where the elevation of the glacier is lowest. At this location, many small fingers of ice melted away or separated from the main ice body and islands of bedrock began to appear (Fig. 4). Some of the change/error in area for each period is likely attributable to changes in personnel conducting the mapping. For certain regions, especially where rock debris conceals and/or distorts the terminus location, different personnel have interpreted

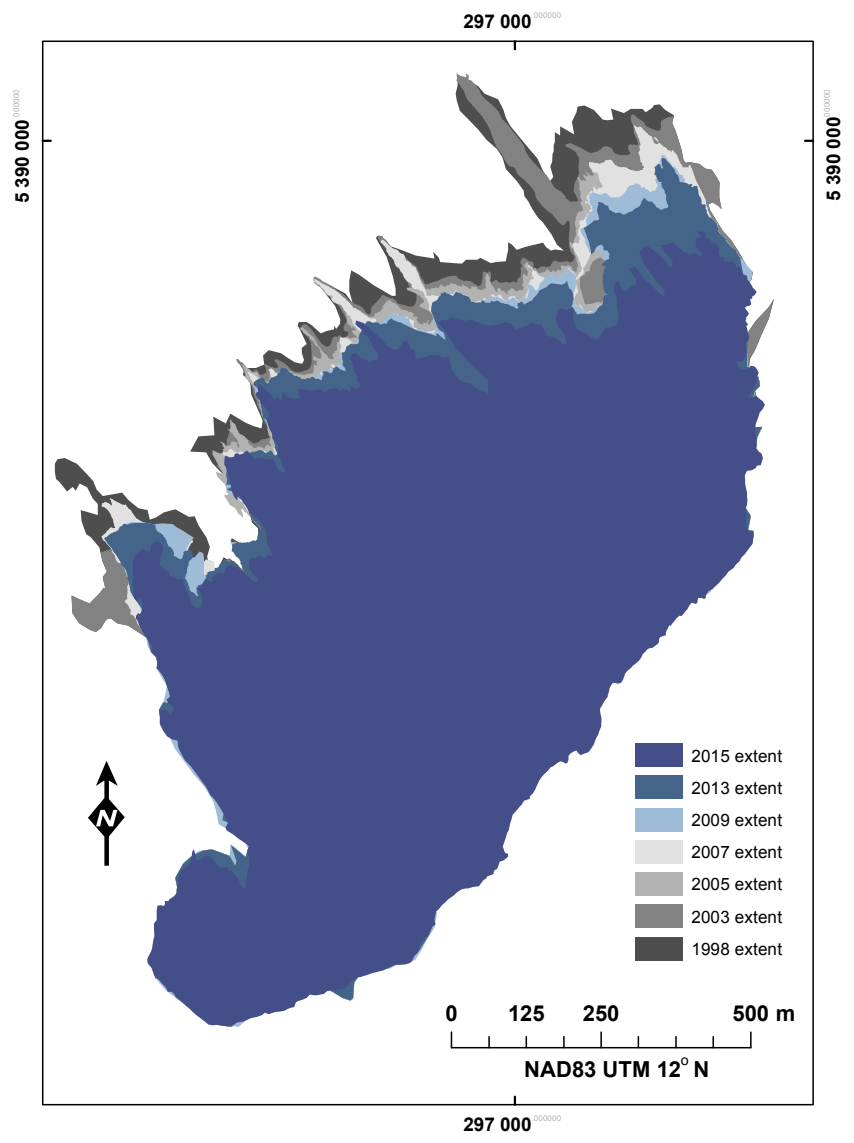

Figure 4. Mapped outlines of Sperry Glacier for the period 19982015.

the margin's location slightly differently. The existence and annual variability of rock-covered ice makes distinguishing ice compared to rock difficult at times. A recent study in the North Cascades, USA, suggest a $5 \%$ error value attributable to these uncertainties for mapping glacier margins (Riedel and Larrabee, 2016).

\subsection{Glacier mapping - accumulation area}

In years 2005, 2009, 2010, and 2013 the accumulation area ratios were $34,46,48$, and $36 \%$ respectively (Supplement). 
Table 4. Summary statistics for 2005-20105 winter point balances.

\begin{tabular}{llrrrrrrr}
\hline Year & $\begin{array}{l}\text { End winter/ } \\
\text { start summer }\end{array}$ & Count & $\begin{array}{r}\text { Mean } \\
(\mathrm{m} \text { w.e. })\end{array}$ & $\begin{array}{r}\text { Median } \\
(\mathrm{m} \text { w.e. })\end{array}$ & $\begin{array}{r}\text { SD } \\
(\mathrm{m} \text { w.e. })\end{array}$ & $\begin{array}{r}\text { Minimum } \\
(\mathrm{m} w . e .)\end{array}$ & $\begin{array}{r}\text { Maximum } \\
(\mathrm{m} \text { w.e. })\end{array}$ & $\begin{array}{r}\text { Range } \\
(\mathrm{m} \text { w.e. })\end{array}$ \\
\hline 2005 & 23-Jun & 82 & 2.36 & 2.10 & 0.83 & 0.00 & 4.12 & 4.12 \\
2006 & 8-Jun & 110 & 2.72 & 2.58 & 0.86 & 0.00 & 5.66 & 5.66 \\
2007 & 26-May & 40 & 2.23 & 2.30 & 0.64 & 0.00 & 3.81 & 3.81 \\
2008 & 16-Jun & 12 & 2.59 & 2.85 & 0.95 & 0.00 & 3.77 & 3.77 \\
2009 & 16-Jun & 96 & 2.31 & 2.13 & 0.91 & 0.00 & 5.05 & 5.05 \\
2010 & 23-Jun & 71 & 2.71 & 2.66 & 0.70 & 0.00 & 4.12 & 4.12 \\
2011 & 24-Jun & 27 & 4.15 & 4.09 & 0.57 & 3.41 & 5.10 & 1.70 \\
2012 & 28-Jun & 19 & 3.25 & 3.05 & 0.98 & 1.81 & 5.42 & 3.61 \\
2013 & 11-Jun & 21 & 2.91 & 2.92 & 0.53 & 2.20 & 4.28 & 2.07 \\
2014 & 11-Jun & 7 & 2.96 & 2.83 & 0.71 & 2.04 & 4.38 & 2.34 \\
2015 & 25-May & 8 & 2.76 & 2.51 & 0.70 & 1.99 & 4.22 & 2.23 \\
Mean & 13-Jun & 45 & 2.81 & 2.73 & 0.76 & 1.04 & 4.54 & 3.50 \\
SD & 11 & 38 & 0.54 & 0.55 & 0.15 & 1.26 & 0.65 & 1.28 \\
Min & 25-May & 7 & 2.23 & 2.10 & 0.53 & 0.00 & 3.77 & 1.70 \\
Max & 28-Jun & 110 & 4.15 & 4.09 & 0.98 & 3.41 & 5.66 & 5.66 \\
Range & 34 & 103 & 1.92 & 1.99 & 0.45 & 3.41 & 1.89 & 3.97 \\
\hline
\end{tabular}

The average value is $41 \%$. While we did not measure the AAR for any other years, we noted that during the two years with the most positive $B_{\text {a }}$ (2008 and 2011), most of the glacier's surface was still covered with snow from the previous winter at the end of the ablation season in late September/early October.

\subsection{Mass balance point measurements $\left(b_{\mathrm{w}}, b_{\mathrm{s}}, b_{\mathrm{a}}\right)$}

When combining all points from all years $(n=477)$, the mean $b_{\mathrm{w}}$ was $2.64 \mathrm{~m}$ w.e. with a standard deviation of $0.88 \mathrm{~m}$ w.e. The minimum was $0.00 \mathrm{~m}$ w.e. (due to windscouring down to bare ice) and the maximum was $5.66 \mathrm{~m}$ w.e. The mean values for all points binned by individual year had a narrower range of $1.92 \mathrm{~m}$ w.e. and a lower standard deviation of $0.54 \mathrm{~m}$ w.e. Snow depth and density plus winter balance values for all measurement points are presented in the tables included in the Supplement. Table 4 details summary statistics for the winter point balances.

A somewhat complicated relationship exists between winter balance and elevation after averaging the $b_{\mathrm{w}}$ values from all years within their respective $50 \mathrm{~m}$ elevation bands (Fig. 5). On the lowest elevation portions of the glacier, between the terminus and about $2400 \mathrm{~m}$, the 11-year averaged winter balances increased gradually with rising elevations. On the middle of the glacier, the winter balances actually decreased slightly with elevation. At this point it is unclear whether these small changes are attributable to measurement error or other factors such as wind erosion. On the upper elevations, winter balances increased rapidly as elevation increased. The deep snow depths found at these points are likely the result of avalanching from the steep headwalls above.

In 2005, 2006, and 2007 the number and locations of ablation stakes varied (Supplement). Beginning in 2008, when

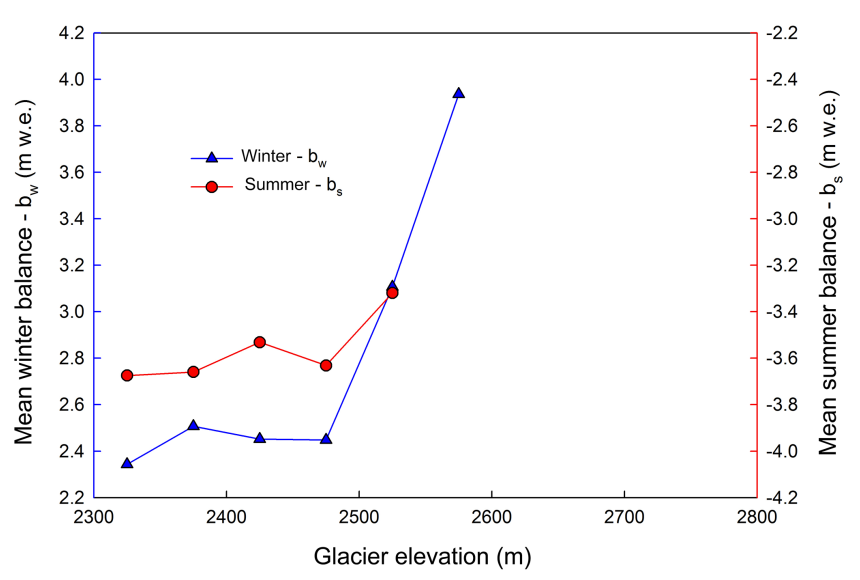

Figure 5. Winter and summer mass balance measurements from all points/all years which were grouped by elevation (NGVD29 and NAD 83) into $50 \mathrm{~m}$ bins. We plotted the mean for each bin against the mean elevation for each bin. The number of measurements in each bin varies within years and among years depending on the year's measurements. The $x$ axis includes the full elevation range of the glacier.

seven stakes were placed in the same locations each year, the winter, summer, and annual balances were measured consistently at each site every year with the exception of one stake in 2009. Stake $Z$ was added in 2015 to better measure the uppermost accumulation zone and to compare balances found at nearby stake D.

Ablation, as reflected in the change of the glacier surface elevation at the ablation stake sites, followed a similar temporal pattern in all 11 years. The surface change was greatest during June and July and sometimes early August with surface lowering rates ranging between -0.06 to $-0.10 \mathrm{~m} \mathrm{~d}^{-1}$ 
Table 5. Summary statistics for 2005-2015 summer point balances.

\begin{tabular}{llrrrrrrr}
\hline Year & $\begin{array}{l}\text { End } \\
\text { summer }\end{array}$ & Count & $\begin{array}{r}\text { Mean } \\
(\mathrm{m} \text { w.e. })\end{array}$ & $\begin{array}{r}\text { Median } \\
(\mathrm{m} \text { w.e. })\end{array}$ & $\begin{array}{r}\text { SD } \\
(\mathrm{m} \text { w.e. })\end{array}$ & $\begin{array}{r}\text { Minimum } \\
(\mathrm{m} \text { w.e. })\end{array}$ & $\begin{array}{r}\text { Maximum } \\
(\mathrm{m} w . e .)\end{array}$ & $\begin{array}{r}\text { Range } \\
(\mathrm{m} \text { w.e. })\end{array}$ \\
\hline 2005 & 9-Sep & 3 & -3.26 & -3.30 & 0.25 & -3.50 & -2.99 & 0.51 \\
2006 & 28-Sep & 8 & -3.71 & -3.89 & 0.41 & -4.18 & -3.01 & 1.17 \\
2007 & 9-Sep & 7 & -3.96 & -4.08 & 0.32 & -4.34 & -3.43 & 0.91 \\
2008 & 12-Sep & 7 & -2.23 & -2.32 & 0.20 & -2.43 & -1.90 & 0.52 \\
2009 & 18-Sep & 6 & -3.90 & -3.82 & 0.25 & -4.23 & -3.63 & 0.61 \\
2010 & 2-Oct & 7 & -2.95 & -3.02 & 0.22 & -3.20 & -2.63 & 0.56 \\
2011 & 3-Oct & 7 & -3.40 & -3.32 & 0.22 & -3.76 & -3.09 & 0.67 \\
2012 & 1-Oct & 7 & -3.56 & -3.55 & 0.23 & -3.88 & -3.26 & 0.62 \\
2013 & 27-Sep & 7 & -4.60 & -4.63 & 0.38 & -4.96 & -3.93 & 1.03 \\
2014 & 18-Sep & 7 & -3.28 & -3.22 & 0.21 & -3.51 & -3.04 & 0.48 \\
2015 & 22-Sep & 8 & -4.21 & -4.35 & 0.51 & -4.91 & -3.33 & 1.58 \\
Mean & 21-Sep & 7 & -3.55 & -3.59 & 0.29 & -3.90 & -3.11 & 0.79 \\
SD & 9 & 1 & 0.64 & 0.65 & 0.10 & 0.74 & 0.53 & 0.35 \\
Min & 9-Sep & 3 & -4.60 & -4.63 & 0.20 & -4.96 & -3.93 & 0.48 \\
Max & 3-Oct & 8 & -2.23 & -2.32 & 0.51 & -2.43 & -1.90 & 1.58 \\
Range & 24 & 5 & 2.37 & 2.31 & 0.31 & 2.53 & 2.03 & 1.10 \\
\hline
\end{tabular}

Table 6. Summary statistics for 2005-2015 annual point balances.

\begin{tabular}{llrrrrrrr}
\hline Year & $\begin{array}{l}\text { End balance } \\
\text { year }\end{array}$ & Count & $\begin{array}{r}\text { Mean } \\
\text { (m w.e.) }\end{array}$ & $\begin{array}{r}\text { Median } \\
\text { (m w.e.) }\end{array}$ & $\begin{array}{r}\text { SD } \\
(\mathrm{m} w . e .)\end{array}$ & $\begin{array}{r}\text { Minimum } \\
(\mathrm{m} \text { w.e. })\end{array}$ & $\begin{array}{r}\text { Maximum } \\
\text { (m w.e.) }\end{array}$ & $\begin{array}{r}\text { Range } \\
(\mathrm{m} \text { w.e. })\end{array}$ \\
\hline 2005 & 9-Sep & 5 & -0.89 & -0.88 & 0.38 & -1.45 & -0.37 & 1.08 \\
2006 & 28-Sep & 8 & -1.13 & -1.14 & 0.57 & -1.89 & -0.26 & 1.63 \\
2007 & 9-Sep & 11 & -1.67 & -1.79 & 0.55 & -2.32 & -0.65 & 1.67 \\
2008 & 12-Sep & 7 & 0.76 & 0.81 & 0.68 & -0.32 & 1.87 & 2.19 \\
2009 & 18-Sep & 6 & -1.62 & -1.84 & 0.90 & -2.40 & 0.15 & 2.55 \\
2010 & 2-Oct & 7 & -0.13 & -0.12 & 0.68 & -0.90 & 1.12 & 2.02 \\
2011 & 3-Oct & 7 & 0.74 & 0.37 & 1.02 & 0.00 & 2.90 & 2.90 \\
2012 & 1-Oct & 7 & 0.01 & 0.06 & 1.13 & -1.33 & 2.07 & 3.40 \\
2013 & 27-Sep & 7 & -1.50 & -1.64 & 0.88 & -2.35 & 0.35 & 2.70 \\
2014 & 18-Sep & 7 & -0.32 & -0.37 & 0.86 & -1.48 & 1.33 & 2.81 \\
2015 & 22-Sep & 8 & -1.45 & -1.94 & 1.14 & -2.63 & 0.89 & 3.52 \\
Mean & 21-Sep & 7 & -0.65 & -0.77 & 0.80 & -1.55 & 0.85 & 2.41 \\
SD & 9 & 1 & 0.91 & 0.98 & 0.25 & 0.87 & 1.13 & 0.76 \\
Min & 9-Sep & 5 & -1.67 & -1.94 & 0.38 & -2.63 & -0.65 & 1.08 \\
Max & 3-Oct & 11 & 0.76 & 0.81 & 1.14 & 0.00 & 2.90 & 3.52 \\
Range & 24 & 6 & 2.43 & 2.74 & 0.76 & 2.63 & 3.55 & 2.44 \\
\hline
\end{tabular}

and a mean rate of $-0.08 \mathrm{~m} \mathrm{~d}^{-1}$. From mid-August until the end of the ablation season in September or October, surface lowering rates dropped consistently among all years and range from -0.01 to $-0.05 \mathrm{~m} \mathrm{~d}^{-1}$ with an average rate of $-0.03 \mathrm{~m} \mathrm{~d}^{-1}$. The decrease in late-summer ablation rates is due to multiple factors. The shorter days with lower sun angles of late summer/early fall combined with the cooler, cloudier, and wetter weather all act to slow ablation. Also, August and early September storms will often deposit small amounts of new snow on the glacier, which slows or temporarily halts ablation.

When combining all stake measurements from all years $(n=74)$, the mean stake $b_{\mathrm{s}}$ was $-3.57 \mathrm{~m}$ w.e., with a range of
$3.06 \mathrm{~m}$ w.e. and a standard deviation of $0.70 \mathrm{~m}$ w.e. The stake means for each year had a narrower range of $2.37 \mathrm{~m}$ w.e. and a standard deviation of $0.64 \mathrm{~m}$ w.e. (Table 5). However, less variance existed within individual years. The range of $b_{\mathrm{s}}$ amongst stakes for individual years spanned 0.51 to $1.58 \mathrm{~m}$ w.e. and the standard deviations ranged from 0.20 to $0.51 \mathrm{~m}$ w.e.

The relationship between summer balance and elevation varied between years and sometimes in a complex manner. When all $b_{\mathrm{S}}$ values from all years were grouped within $50 \mathrm{~m}$ elevation bands and averaged, $b_{\mathrm{s}}$ did not consistently increase with increasing elevation (Fig. 5). At points above $2500 \mathrm{~m}$ ablation was noticeably lower. This is due to the 
Table 7. Glacier-wide balances. Units are m w.e. for all values.

\begin{tabular}{lrr|rr|rrr}
\hline & \multicolumn{2}{c|}{ Winter balance } & \multicolumn{2}{|r|}{ Summer balance } & Annual balance & \\
\cline { 2 - 6 } Year & $\begin{array}{r}b_{\mathrm{W}}: \\
\text { mean measured } \\
\text { points }\end{array}$ & $\begin{array}{r}B_{\mathrm{W}}: \\
\text { site } \\
\text { index }\end{array}$ & $\begin{array}{r}b_{\mathrm{s}}: \\
\text { mean } \\
\text { stakes }\end{array}$ & $\begin{array}{r}B_{\mathrm{s}}: \\
\text { site } \\
\text { index }\end{array}$ & $\begin{array}{r}b_{\mathrm{a}}: \\
\text { mean } \\
\text { stakes }\end{array}$ & $\begin{array}{r}B_{\mathrm{a}}: \\
\text { site } \\
\text { index }\end{array}$ & $\begin{array}{r}\text { cumulative } \\
\text { Site } \\
\text { Index }\end{array}$ \\
\hline 2005 & 2.36 & 2.33 & -3.26 & -3.25 & -0.89 & -0.85 & -0.85 \\
2006 & 2.74 & 2.78 & -3.71 & -3.48 & -1.13 & -0.75 & -1.60 \\
2007 & 2.23 & 2.19 & -3.96 & -3.93 & -1.67 & -1.52 & -3.12 \\
2008 & 2.59 & 2.74 & -2.23 & -2.11 & 0.76 & 0.97 & -2.15 \\
2009 & 2.31 & 2.46 & -3.90 & -3.86 & -1.62 & -1.39 & -3.54 \\
2010 & 2.71 & 2.82 & -2.95 & -2.80 & -0.13 & 0.15 & -3.39 \\
2011 & 4.15 & 4.13 & -3.40 & -3.21 & 0.74 & 0.83 & -2.56 \\
2012 & 3.25 & 3.67 & -3.56 & -3.42 & 0.01 & 0.41 & -2.15 \\
2013 & 2.91 & 2.97 & -4.60 & -4.31 & -1.50 & -1.07 & -3.22 \\
2014 & 2.96 & 3.19 & -3.28 & -3.17 & -0.32 & 0.07 & -3.15 \\
2015 & 2.77 & 2.79 & -4.21 & -4.01 & -1.45 & -1.22 & -4.37 \\
\hline Mean & 2.82 & 2.92 & -3.55 & -3.41 & -0.65 & -0.40 & \\
SD & 0.54 & 0.57 & 0.64 & 0.62 & 0.91 & 0.91 & \\
\hline
\end{tabular}

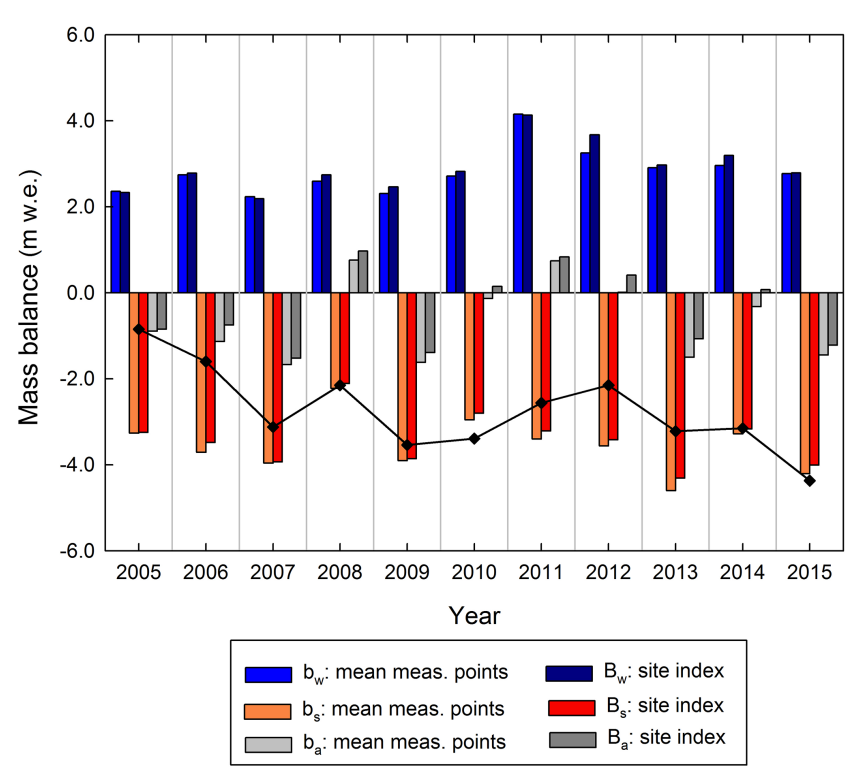

Figure 6. Bars represent the seasonal and annual mass balances on the glacier. The black line depicts the running cumulative balance for the period of record.

shade provided by the steep cirque walls located above this part of the glacier.

When combining the annual point balances from all stakes from 2005 to $2015(n=80)$, the 11-year mean stake $b_{\mathrm{a}}$ was $-0.70 \mathrm{~m}$ w.e., with a range of $5.53 \mathrm{mw}$.e. and a standard deviation of $1.18 \mathrm{~m}$ w.e. The mean $b_{\mathrm{a}}$ for each year varied between $-1.55 \mathrm{~m}$ w.e. and $0.85 \mathrm{~m}$ w.e. (Table 6 ). The range amongst all measurement points for individual years was lower as well and spanned 1.08 to $3.52 \mathrm{~m}$ w.e. with standard deviations falling between 0.38 and $1.14 \mathrm{~m}$ w.e.

\subsection{Glacier-wide mass balances}

\subsubsection{Winter mass balances $\left(B_{\mathrm{w}}\right)$}

The site index method resulted in $B_{\mathrm{w}}$ values ranging from $2.19 \mathrm{~m}$ w.e. in 2007 to $4.13 \mathrm{~m}$ w.e. in 2011 with a mean of $2.92 \mathrm{~m}$ w.e. for 2005-2015 (Table 7). For the first five years, $B_{\mathrm{w}}$ never exceeded $2.78 \mathrm{~m}$ w.e. But from 2010 to 2014 winter accumulation values consistently added more mass to the glacier, with $B_{\mathrm{w}}$ exceeding $3.00 \mathrm{~m}$ in 2011, 2012, and 2014 . In 2015 the winter balance dipped below the 11-year average with a value of $2.79 \mathrm{~m}$ (Fig. 6).

$B_{\mathrm{w}}$ contour maps reveal a sometimes complicated relationship between winter mass balance and elevation (Supplement). For all years except 2005, 2012, and 2015, the mid-elevations between 2400 and $2500 \mathrm{~m}$ had winter balance values that were less than those found at lower elevations (Fig. 7). For instance, during years 2007-2010, 2013, and 2014 winter balance values at these mid-elevations were the lowest of any elevation band on the glacier. Winter balances increased rapidly with an elevation above $2500 \mathrm{~m}$ until the bergschrund located at the base of the cirque wall at about $2650 \mathrm{~m}$. On the headwall above the bergschrund winter balances are assumed to decrease because of mass redistribution to the slopes below, likely through avalanches and wind transport.

\subsubsection{Summer mass balances $\left(B_{\mathrm{S}}\right)$}

$B_{\mathrm{s}}$ values ranged from -4.31 in 2013 to $-2.11 \mathrm{~m}$ w.e. in 2008 with a mean for the 11 -year record of $-3.41 \mathrm{~m}$ w.e. (Table 7). The summers of 2013 and 2015 were exceptional for ablation and were the only two years where $B_{\mathrm{S}}$ was lower than $-4.00 \mathrm{~m}$ w.e. In 2008 and 2010 the glacier had the 


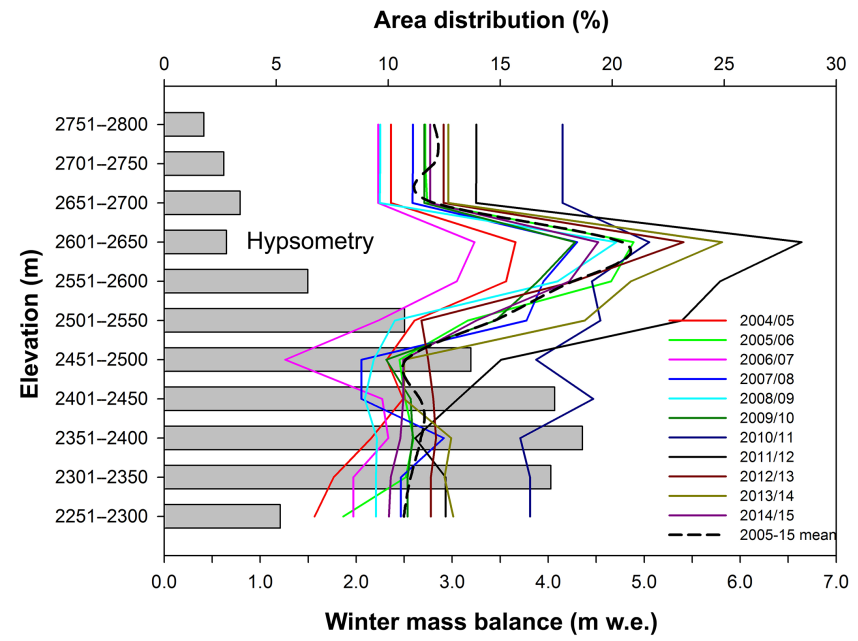

Figure 7. Winter mass balances for years 2005-2015 plotted against each elevation (NGVD29 and NAD83) band. Area altitude distribution is from 2005. Gray bars represent the percentage of glacier area within each elevation band. Colored lines plot the winter mass balances across the elevation range of the glacier.

least amount of summer ablation and $B_{\mathrm{S}}$ did not drop below $-3.00 \mathrm{~m}$ w.e. For all other years $B_{\mathrm{s}}$ values ranged between -3.93 and $-3.17 \mathrm{~m}$ w.e. (Fig. 6).

Similar to the winter balances, summer mass balances did not always vary consistently with elevation (Fig. 8). For years 2005, 2006, 2008, and $2010 B_{\mathrm{s}}$ continually became more negative, although sometimes only slightly, with increasing elevation. For the remaining years the most negative summer balance values were often found on areas of the glacier between 2350 and $2400 \mathrm{~m}$. Some general trends are revealed when the summer balances for each elevation band were averaged for the period of record. Mean summer balances vary only by a few centimeters w.e. between the terminus at about 2250 and $2500 \mathrm{~m}$, an area encompassing most of the glacier. Above $2500 \mathrm{~m}$ summer balances increase at a fairly consistent rate of about $0.25 \mathrm{~m}$ w.e. per $50 \mathrm{~m}$ elevation gain (Fig. 8).

\subsubsection{Annual mass balances $\left(B_{\mathrm{a}}\right)$}

The first three balance years, 2005-2007, were strongly negative with 2007 having the lowest $B_{\mathrm{a}}$ on record at $-1.52 \mathrm{~m}$ w.e. In 2008 , conditions reversed and the glacier experienced its most strongly positive year with a $B_{\mathrm{a}}$ of $0.97 \mathrm{~m}$ w.e.; 2009 was the second most negative year at -1.39 m w.e. and then in 2010 the annual balance was near neutral with a value of $0.15 \mathrm{~m}$ w.e. The annual balance in 2011 was the second most positive at $0.83 \mathrm{~m}$ w.e., and the balance in 2012 was slightly positive as well at $0.41 \mathrm{~m}$ w.e. The three years of neutral or positive annual balances ended in 2013 with a value of -1.07 . Annual balance in 2014 was neutral ( $0.07 \mathrm{~m}$ w.e.), and finally the annual balance in 2015 was the third most negative year on record ( $-1.22 \mathrm{~m}$ w.e.; Fig. 6).

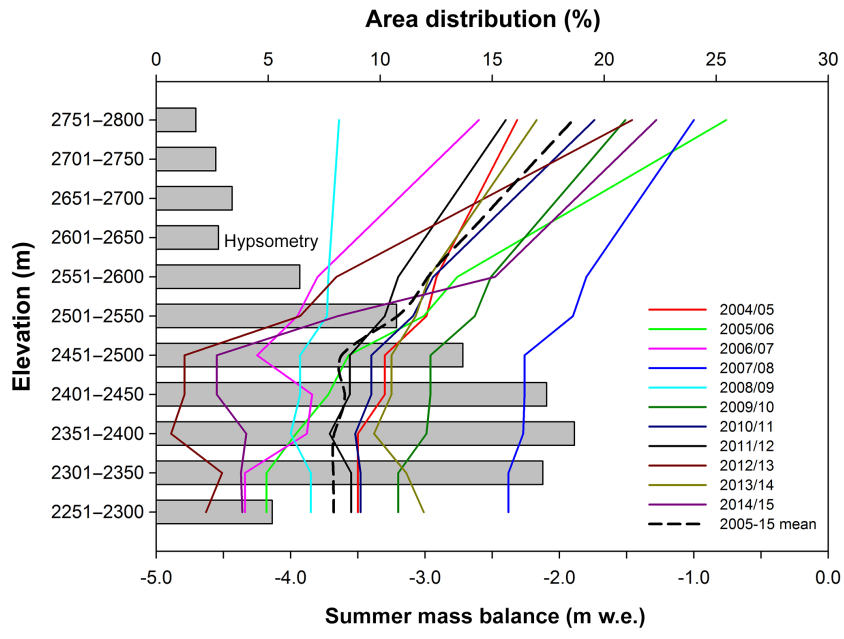

Figure 8. Summer mass balances for years 2005-2015 plotted against each elevation (NGVD29 NAD83) band. Area altitude distribution is from 2005. Gray bars represent the percentage of glacier area within each elevation band. Colored lines plot the summer mass balances across the elevation range of the glacier.

The mean site index $B_{\mathrm{a}}$ for the study period is $-0.40 \mathrm{~m}$ w.e. (Table 7).

Again, similar to the winter and summer balances, the changes in annual balances with elevation were variable (Fig. 9 and Supplement). For years 2005, 2006, 2010, and $2012 B_{\text {a }}$ continually increased, although at different rates, with increasing elevation from the terminus to the bergschrund at $2650 \mathrm{~m}$. However, for the seven remaining individual balance years, the lowest annual balances were found at the mid-elevations between 2400 and $2500 \mathrm{~m}$. The annual balance values on the headwall above the bergschrund are reduced, with negative values in 2005, 2007, and 2009. It is important to note again that balances on this section of the glacier come with high uncertainty because they are not measured directly. However, observations revealed some years where the headwall is composed mostly of ice and would thus have negative balances, while the slopes immediately below it and the bergschrund are still covered in the previous winter's snow and would have maintained a positive balance.

\subsection{Cumulative mass balances}

Cumulatively the glacier lost $4.37 \mathrm{~m}$ w.e. between 2005 and 2015 by way of the site index method. About $70 \%$ of that loss occurred during the first three years of the study. Both seasonal and annual balances exhibited more variability in the remaining eight years of the study.

Cumulative balances in the ablation zone, which averaged about $60 \%$ of the glacier area for the four years it was measured, ranged from -11.28 to $-9.79 \mathrm{~m}$ w.e. Meanwhile in the accumulation zone, cumulative balances were as low as $3.38 \mathrm{~m}$ w.e. and as high as $21.94 \mathrm{~m}$ w.e. in the region directly 


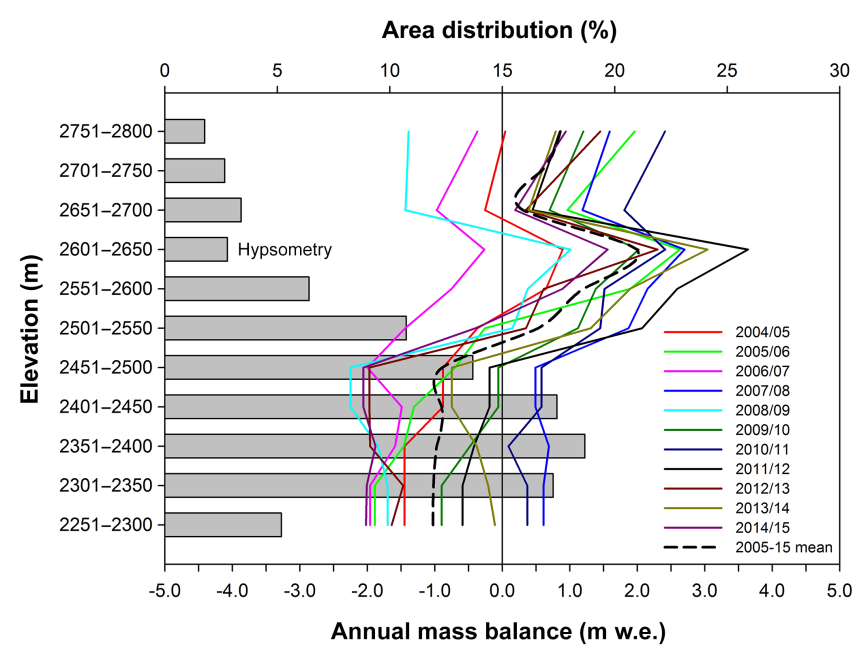

Figure 9. Annual mass balances for years 2005-2015 plotted against each elevation (NGVD29 and NAD83) band. Area altitude distribution is from 2005. Gray bars represent the percentage of glacier area within each elevation band. Colored lines plot the annual mass balances across the elevation range of the glacier.

beneath the headwall. These differences translate to cumulative balances that change as much as $30.00 \mathrm{~m}$ w.e. over less than $400 \mathrm{~m}$ of linear distance and less than $200 \mathrm{~m}$ of elevation gain.

\subsection{Sources and estimates of error}

Errors associated with measurements of snow depth and density, ablation, stake and probe point locations, and the fact that measurements are never taken on the exact day of glacier maximum and minimum balances all may affect the individual point balances. There is uncertainty as to how well the point balances represent their respective elevation bands and what this effect may have on the glacier-wide values. Our accumulation area measurements have shown that some bands contain zones of both accumulation and ablation during some years. And finally certain areas of the glacier simply cannot be measured due to safety concerns. A developing understanding of the accumulation and ablation patterns over time has been used to develop the current stake network and now fewer measurements are made at strategic locations. Yet we acknowledge that the optimal number and distribution of measurement points on the glacier still needs to be resolved. We have not yet done a complete quantitative error analysis. However we summarize the major sources of uncertainty associated with the Sperry program and also offer error estimates based on other similar work.

Because they are time- and labor-intensive to conduct, density measurements are sparse compared to depth measurements. Due to the small amount of data, it is uncertain how much density varies temporally and spatially. During the 2009-2013 balance years no density measurements

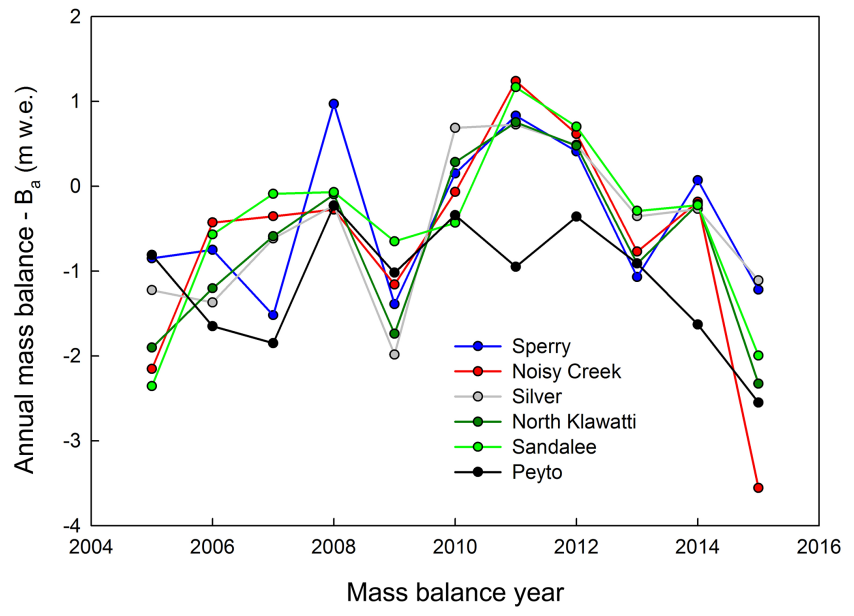

Figure 10. Glacier-wide annual mass balances $\left(B_{\mathrm{a}}\right)$ plotted for Sperry Glacier, four glaciers in North Cascades National Park, USA, and Peyto Glacier in the Canadian Rockies during years 2005-2015.

were made, which introduces additional uncertainty for those years. Nevertheless, our limited measurements suggest spatial variability of snow density across the glacier surface is minimal near the time of maximum balance. Measurements made on the same day but at different locations result in mean values that vary by less than $50 \mathrm{~kg} \mathrm{~m}^{-3}$. Temporal variability is slightly higher with bulk mean values ranging between 462 and $596 \mathrm{~kg} \mathrm{~m}^{-3}$ among the six years when snow density was measured.

A more critical source of error lies in the problem of accurately measuring snow depths. It can be difficult to determine the previous summer's surface through several meters of snow, especially in the accumulation zone. Multiple probe measurements made at one point were used to address this problem. One approach to quantifying the effects of errors follows Jansson (1999), who identified systematic probing errors as the most likely to create relatively large uncertainties in the winter balance. He argued that small random errors will cancel out, larger random errors will be detected as islands of anomalous depth, but systematic errors in resolving the previous summer surface are restricted to the accumulation area and are often proportional to snow depth. Beginning in 2014 we cored through the entire winter's snowpack and obtained a definitive depth to ice or firn at two to three of the stake sites. These depths were consistent with those sounded by probing at the same locations.

The ablation stake measurements are subject to stake sinking, which will underestimate summer balance, and to recording blunders made in the field. Partitioning the snow, firn, and ice components of height loss also proved difficult in some instances. Firn density was not measured, forcing us to use an estimated value. The spatial variability of ablation across the glacier surface could be examined more thor- 
oughly through the use of more stakes placed in different locations.

Jansson (1999) suggests a glacier-wide mass balance uncertainty value of approximately $0.10 \mathrm{~m}$ w.e. for glaciers with sparse networks of measurement points. Riedel and Larrabee (2011) with the US National Park Service have derived error values for the winter, summer, and annual point balances on four glaciers in the North Cascades, USA, years 1993-2009. Winter point balance errors ranged from 0.19 to $0.26 \mathrm{mw}$.e., summer point balance errors from 0.26 to $0.33 \mathrm{~m}$ w.e., and annual point balance errors from 0.31 to $0.42 \mathrm{~m}$ w.e. A complete description of this program's error analysis can be found in Riedel et al. (2008). At this time it is unclear what error values are appropriate for both the point and glacier-wide mass balances on Sperry Glacier. The Sperry program methods are similar to those used by the $\mathrm{Na}$ tional Park Service in the North Cascades and by many other programs worldwide cited in Jansson (1999). Uncertainties ranging between \pm 0.20 and $0.50 \mathrm{~m}$ w.e. would be reasonable estimates for the Sperry Glacier balances. Future work will attempt to estimate the errors associated with our results in a more thorough fashion.

\subsection{Regional comparisons of annual and cumulative mass balances}

There are no other glacier mass balance programs in the US northern Rockies that can be compared to Sperry Glacier. However some general comparisons can be made with the Peyto Glacier mass balance record from the Canadian Rockies and mass balances from four glaciers in the North Cascades, USA (WGMS, 2016; Riedel and Larrabee, 2016), where mass balances are calculated with methods similar to those used on Sperry Glacier.

At Peyto Glacier between 2005 and 2015, the cumulative mass balance was $-12.30 \mathrm{~m}$ w.e., almost $8 \mathrm{~m}$ more negative than Sperry during the same time period. Peyto experienced no positive balance years, while Sperry had two positive balance years in 2008 and 2011 (Fig. 10). Interestingly, in 2011 $B_{\mathrm{a}}$ on Peyto was the sixth most negative for the 2005-2015 record. Meanwhile the second highest $B_{\mathrm{a}}$ on Sperry occurred that same year. Both glaciers lost substantial mass in 2005, 2007, 2009, 2013, and 2015.

A comparison of annual and cumulative balances with four glaciers in the North Cascades - Noisy Creek, Silver, North Klawatti, and Sandalee glaciers - showed similar general trends to those observed on Sperry (Fig. 10). Cumulative balances for years 2005-2015 were all more negative than Sperry Glacier and ranged from $-7.47 \mathrm{~m}$ w.e. on North Klawatti Glacier to $-4.81 \mathrm{~m}$ w.e. on Sandalee Glacier. All four North Cascade glaciers had positive annual balances in 2011. The only other positive $B_{\text {a }}$ on Sperry occurred in 2008, but the four glaciers in the Cascades all had slightly negative annual balances during that year. Like Peyto and Sperry, all four of these glaciers had strongly negative annual bal- ances in 2005, 2009, and 2015. But unlike Sperry and Peyto, mass losses were not as great in 2013 on Silver and Sandalee glaciers. The North Cascade glaciers seemed to fare better in 2007 as well, with less negative annual balances. In contrast the most negative annual balance on Sperry occurred in 2007.

\section{Conclusions}

Conventional glacier-wide seasonal and annual mass balances were estimated using glaciological methods from 2005 to 2015 at Sperry Glacier and reported along with all the accompanying glaciological measurements. Measurements of glacier extent and accumulation areas were also measured during certain years and are included in this paper as well.

Results from our site index methods reveal that, on average, Sperry Glacier loses about $0.40 \mathrm{~m}$ w.e. each year (mean $B_{\mathrm{a}}$ ). During the 11-year study period, glacier-wide winter balances ranged from 2.19 to $4.13 \mathrm{~m}$ w.e., glacier-wide summer balances between -4.31 and $-2.11 \mathrm{~m}$ w.e., and annual glacier-wide balances between -1.52 and $0.97 \mathrm{~m}$ w.e. The mean winter and summer glacier-wide mass balances were 2.92 and $-3.41 \mathrm{~m}$ w.e. respectively.

The range between point balances was greater than the glacier-wide values. Some winter point balances exceeded $5.00 \mathrm{~m}$ w.e., while at other locations on the same day there were patches of bare ice with no winter accumulation. During particularly hot and long summers, summer point balances approached $-5.00 \mathrm{~m}$ w.e. at certain locations.

Between 2005 and 2015, it is estimated Sperry Glacier lost $4.37 \mathrm{~m}$ w.e. averaged over its entire area. In the ablation zone, cumulative balances reached as low as $-11.28 \mathrm{~m}$ w.e. In the accumulation zone, cumulative balances ranged from as little as 3.38 all the way up to $21.94 \mathrm{mw}$.e. in areas directly beneath the headwall. Overall the Sperry record is mostly consistent with other mass balance records from four other glaciers in the North Cascades in the United States and one glacier in the Canadian Rockies. However, an examination of cumulative balances suggests Sperry is losing mass at a slightly slower rate when compared to these five other glaciers.

Sperry's surface area has decreased by $0.08 \mathrm{~km}^{2}$ over the 2005-2015 time period, a change of about $9 \%$. Most of this decrease occurred in the northeastern section, the lowest elevation area of the glacier.

The variable relationship between mass balance and altitude on Sperry is likely affected by concurrent multiple drivers that are not yet fully understood. Further research is needed to improve our knowledge of the processes that control accumulation and ablation patterns on this glacier. Specific to ablation, local factors that regulate the balance of heat energy input from solar radiation such as aspect, slope angle, and cirque-wall shading, combined with the type of material present on the glacier's surface, may have a greater 
influence on ablation rates than the gradient between altitude and air temperatures. The winter balance is likely bolstered by the snow added to the glacier from avalanches and wind, especially in the areas directly beneath the cirque walls, but this re-distribution of mass needs to be better quantified. Our findings are comparable with other work which shows small alpine cirque glaciers are more sensitive to these topographic factors that can influence the surface mass balance (Kuhn, 1995; Hoffman et al., 2007; Fountain, 2007; Fountain and Vecchia, 1999). Future work will focus on obtaining better data, especially in the accumulation zone with specific attention given to adding and/or adjusting the measurement site locations and to sampling the depth and density of snow and/or firn at the end of the ablation season. In addition we plan to complete a thorough examination of the errors and uncertainties associated with the methods we use on Sperry and to compare our glaciological results against geodetic mass balances.

\section{Data availability}

All data have been submitted to the World Glacier Monitoring Service and are available at doi:10.5904/wgms-fog-201608. In addition, the Supplement containing all data related to this article.

\section{The Supplement related to this article is available online at doi:10.5194/essd-9-47-2017-supplement.}

Acknowledgement. This research was supported by the US Geological Survey's Climate and Land Use Change Research and Development Program. Help with fieldwork was provided by a large group of field technicians and volunteers over the years. The authors would like to thank Mauri Pelto, Jon Riedel, and one anonymous reviewer for their helpful comments and insight, which greatly improved this paper. Any use of trade, firm, or product names is for descriptive purposes only and does not imply endorsement by the US government.

Edited by: R. Drews

Reviewed by: M. Pelto and one anonymous referee

\section{References}

Alden, W. C.: Glaciers of Glacier National Park, US Dept. of the Interior, Washington D.C., 48 pp., 1914.

Alden, W.C.: Rate of movement in glaciers of Glacier National Park, Science, 57, 268, 1923.

Brown, J., Harper J., and Humphrey, N.: Cirque glacier sensitivity to 21 st century warming: Sperry Glacier, Rocky Mountains, USA, Global Planet. Change, 74, 91-98, doi:10.1016/j.gloplacha.2010.09.001, 2010.
Carrara, P. E.: Late quaternary glacial and vegetative history of the Glacier National Park region, Montana, US Geol. Surv. Bulletin 1902, US Dept. of the Interior, Washington D.C., 64 pp., 1989.

Carrara, P. E. and McGimsey, R. G.: The late-neoglacial histories of the Agassiz and Jackson Glaciers, Glacier National Park, Montana, Arct. Alp. Res., 13, 183-196, 1981.

Carrara, P. E. and McGimsey, R. G.: Map showing distribution of moraines and extent of glaciers from the mid-nineteenth century to 1979 in the Mount Jackson area, Glacier National Park, Montana, US Geol. Surv. Miscellaneous Investigations Series, US Dept. of the Interior, Washington D.C. 1988.

Clark, A. M., Harper, J. T., and Fagre, D. B.: Glacier-Derived August Runoff in Northwest Montana, Arct. Antarct. Alp. Res., 47, 1-16, doi:10.1657/AAAR0014-033, 2015.

Cogley, J. G., Hock, R., Rasmussen L. A., Arendt, A. A., Bauder, A., Braithwaite, R. J., Jansson, P., Kaser, G., Moller, M., Nicholson, L., and Zemp, M.: Glossary of Mass Balance and Related Terms. IHP-VII Technical Documents in Hydrology No. 86, IACS Contribution No. 2, UNESCO-IHP, Paris, 2011.

Cuffey, K. M. and Paterson, W. S. B.: The Physics of Glaciers 4th Edn., Elsevier, Burlington MA, USA and Oxford, UK, 2010.

Dyson, J. L.: Shrinkage of Sperry and Grinnell Glaciers, Glacier National Park, Montana, Geogr. Rev., 38, 95-103, 1948.

Fahey, M.: National Civil Applications Program, US Geol. Surv., Denver, CO, USA, 2014.

Finklin, A. I.: A Climatic Handbook for Glacier National Park: With Data for Waterton Lakes National Park, US Forest Service Intermountain Research Station, Ogden, UT, 1986.

Fountain, A. G.: A century of glacier change in the American West, EOS Trans. of the American Geophysical Union, 88, 52, 2007.

Fountain, A. G. and Vecchia, A.: How many stakes are required to measure the mass balance of a glacier?, Geogr. Ann. A, 81, 563573, 1999.

Fountain A. G., Krimmel, R. M., and Trabant, D. C.: A strategy for monitoring glaciers, US Geol. Surv. Circular 1132, US Government Printing Office, Washington D.C., 1997.

Hall, M. H. P. and Fagre, D. B.: Modeled climate-induced glacier change in Glacier National Park, 1850-2100, BioScience, 53, 131-140, 2003.

Hoffman, M. J., Fountain, A. G., and Achuff, J. M.: 20th century variations in area of cirque glaciers and glacierets, Rocky Mountain National Park, Rocky Mountains, Colorado, USA, Ann. Glaciol., 46, 349-354, 2007.

IPCC, 2013: Climate Change 2013: The Physical Science Basis, Contribution of Working Group I to the Fifth Assessment Report of the Intergovernmental Panel on Climate Change, edited by: Stocker, T. F., Qin, D., Plattner, G.-K., Tignor, M., Allen, S. K., Boschung, J., Nauels, A., Xia, Y., Bex, V., and Midgley, P. M., Cambridge University Press, Cambridge, United Kingdom and New York, NY, USA, 1535 pp., doi:10.1017/CBO9781107415324, 2013.

Jansson, P.: Effect of uncertainties in measured variables on the calculated mass balance of Storglaciaren, Geogr. Ann., 81, 633642, 1999.

Johnson, A.: Grinnell and Sperry Glaciers, Glacier National Park, Montana: a record of vanishing ice, US Government Printing Office, Washington D.C., 1980. 
Kaser, G., Fountain, A., Jansson, P., Heucke, E., and Knaus, M.: A manual for monitoring the mass balance of mountain glaciers: UNESCO, 137 pp., 2003.

Key, C. H., Fagre, D. B., and Menicke, R. K.: Satellite image atlas of glaciers of the world, glaciers of North America - Glaciers of the western United States, J365-J381, US Government Printing Office, Washington D.C., 2002.

Kuhn, M.: The mass balance of very small glaciers, Z. Gletsch. Glazia, 31, 171-179, 1995.

McCabe, G. J. and Dettinger, M. D.: Primary Modes and Predictability of Year-to-Year Snowpack Variations in the Western United States from Teleconnections with Pacific Ocean Climate, J. Hydrometeorol., 3, 13-25, 2002.

Natural Resources Conservation Service Snow Telemetry (SNOTEL) and Snow Course Data and Products, United States Dept. of Agriculture, available at: http://www.wcc.nrcs.usda.gov/snow/ index.html, last access: 9 August 2016.

Ostrem, G. and Brugman, M.: Glacier Mass Balance Measurements: A Manual for Field and Office Work, Ministry of Supply and Services - Env. Canada and Norwegian Water and Energy Admin, 224 pp., 1991

Pederson, G. T., Fagre, D. B., Gray, T., and Graumlich, L. J.: Decadal-scale climate drivers for glacial dynamics in Glacier National Park, Montana, USA, Geophys. Res. Lett. 31, L12202, doi:10.1029/2004GL019770, 2004.

Pederson, G. T., Gray, S. T., Ault, T., Marsh, W., Fagre, D. B., Bunn, A. G., Woodhouse, C. A., and Graumlich, L. J.: Climatic controls on the snowmelt hydrology of the northern Rocky Mountains, J. Climate, 24, 1666-1687, doi:10.1175/2010JCLI3729.1, 2011.

Pelto, M. S.: Changes in glacier and alpine runoff in the North Cascade range, Washington, USA 1985-1993, 10, 1173-1180, 1996.

Riedel, J. L. and Larrabee, M. A.: Impact of recent glacial recession on summer streamflow in the Skagit River, Northwest Sci. 90, 5-22, doi:10.3955/046.090.0103, 2016.
Riedel, J. L. and Larrabee, M. A.: North Cascades National Park Complex glacier mass balance monitoring annual report, water year 2009, North Coast and Cascades Network, Natural Resource Technical Report, NPS/NCCN/NRTR, 2011/483, US National Park Service, Natural Resources Stewardship and Science, Fort Collins, CO, 2011.

Riedel, J. L., Burrows, R. A., and Wenger, J. M.: Long-term monitoring of small glaciers at North Cascades National Park: a prototype park model for the North Coast and Cascades Network, Natural Resource Technical Report, NPS/NCCN/NRR, 2008/066, US National Park Service, Fort Collins, CO, 2008.

Roe, G. H., Baker, M. B., and Herla, F.: Centennial glacier retreat as categorical evidence of regional climate change, Nat. Geosci., doi:10.1038/NGEO2863, 2016.

Selkowitz, D. J., Fagre, D. B., and Reardon, B. A.: Interannual variations in snowpack in the Crown of the Continent Ecosystem, Hydrol. Process., 16, 3651-3665, 2002.

USGS Glacier Studies, United States Dept. of the Interior, Geological Survey, available at: https://www2.usgs.gov/climate_landuse/ clu_rd/glacierstudies/, last access: 15 December 2016.

WGMS: Fluctuations of glaciers database, World Glacier Monitoring Service, Zurich, Switzerland, doi:10.5904/wgms-fog-201608, 2016.

Zhang, B.: Towards a higher level of automation in softcopy photogrammetry: NGATE and LIDAR processing in SOCET SET ${ }^{\circledR}$, GeoCue Corporation 2nd Annual Technical Exchange Conference, Nashville, TN, 26-27 Sept, Unpaginated CD-ROM, 32 pp., 2006a.

Zhang, B., Miller, S., DeVenecia, K., and Walker, S.: Automatic terrain extraction using multiple image pairs and back matching, Presented paper, ASPRS 2006 Annual Conference, Reno, NV, 1-5 May, 40 pp., 2006 b. 